\title{
Fowl adenovirus Group I as a causal agent of inclusion body hepatitis/hydropericardium syndrome (IBH/HPS) outbreak in brazilian broiler flocks ${ }^{1}$
}

\author{
Elena Mettifogo ${ }^{2}$, Luis F.N. Nuñez², Silvana H. Santander Parra², \\ Claudete S. Astolfi-Ferreira ${ }^{2}$ and Antonio J. Piantino Ferreira ${ }^{2 *}$
}

\begin{abstract}
Mettifogo E., Nuñez L.F.N., Santander Parra S.H., Astolfi-Ferreira C.S. \& Ferreira A.J.P. 2014. Fowl adenovirus Group I as a causal agent of inclusion body hepatitis/ hydropericardium syndrome (IBH/HPS) outbreak in brazilian broiler flocks. Pesquisa Veterinária Brasileira 34(8):733-737. Departamento de Patologia, Faculdade de Medicina Veterinária e Zootecnia, Universidade de São Paulo, Av. Prof. Dr. Orlando Marques de Paiva 87, São Paulo, SP 05508-270, Brazil. E-mail: ajpferr@usp.br

Commercial broiler flocks from a farm located in the State of São Paulo, Brazil, presented diarrhea, depression, increased mortality and poor weight gain. Upon post-mortem examination, classical signs of Inclusion Body Hepatitis/Hydropericardium Syndrome (IBH/HPS) were observed, including enlarged pale yellow-colored livers and straw-colored liquid in the pericardial sac. In addition, gross lesions were also observed in the kidneys, pancreas, thymus, intestines and gallbladder. Samples of these organs were analyzed by PCR for the detection of the hexon gene of the Fowl Adenovirus (FAdVs) Group I. The results were positive for both flocks (A and B) assayed by PCR. The macroscopic lesions associated with the detection of FAdV Group I by PCR in several of these affected organs allowed for the identification of IBH/HPS. In fact, this is the first report in Brazil of IBH/HPS in broilers, which identifies FAdVs group I as a causal agent of the disease. These findings may contribute to the worldwide epidemiology of the adenovirus-mediated hepatitis/ hydropericardium syndrome.
\end{abstract}

INDEX TERMS: Fowl adenovirus, hepatitis, hydropericardium, IBH/HPS syndrome, chicken.

RESUMO.- [Adenovirus aviário Ggrupo I como um agente causal da síndrome da hepatite por corpúsculo de inclusão/hidropericárdio (IBH/HPS) em lotes de frangos de corte.] Lotes comerciais de frangos de uma granja localizada no Estado de São Paulo, Brasil, apresentavam diarreia, depressão, aumento de mortalidade e baixo ganho de peso. Após o exame post-mortem, sinais clássicos da síndrome de hepatite por corpúsculo de inclusão/hidropericárdio (IBH/HPS) foram observados incluindo hepatomegalia com aspecto amarelado pálido e líquido de coloração amarelo palha no saco pericárdio. Além disso, as alterações macroscópicas foram também observadas nos rins, pâncreas, timo, intestinos e vesícula biliar. Amostras destes órgãos foram

\footnotetext{
${ }^{1}$ Received on November 27, 2013.

Accepted for publication on June 23, 2014.

${ }^{2}$ Departamento de Patologia, Faculdade de Medicina Veterinária e Zootecnia, Universidade de São Paulo (USP), Av. Prof. Dr. Orlando Marques de Paiva 87, São Paulo, SP05508-270, Brazil. *Corresponding author: ajpferr@usp.br
}

analisadas pela técnica de PCR para detectar o adenovírus aviário do grupo I através do gene Hexon. Os resultados foram positivos para ambos os lotes (A e B) utilizando-se a técnica de PCR. As lesões macroscópicas associadas à detecção do adenovírus aviário do grupo I pela técnica de PCR em vários destes órgãos acometidos permitiu a identificação da síndrome de hepatite/hidropericárdio em frangos no Brasil. Ao nosso conhecimento, este é a primeira descrição da síndrome de hepatite/hidropericárdio causado por adenovírus aviário do grupo I, no Brasil. Estes achados podem contribuir com a epidemiologia mundial do adenovírus mediando a síndrome de hepatite/hidropericárdio.

TERMOS DE INDEXAÇÃO: Adenovírus aviário, síndrome hepatite por corpúsculo de inclusão/hidropericárdio, IBH/HPS, galinha.

\section{INTRODUCTION}

Fowl Adenovirus (FAdVs) expression appears to be ubiquitous in domesticated fowl and is often isolated from asymptomatic chickens (McFerran \& Adair 2003, Wang 
et al. 2011). However, the hepatitis syndrome characterized by corpuscle inclusion (Inclusion Body Hepatitis-IBH) has attracted the attention of the poultry industry and the scientific community since the emergence of IBH in the 1960s and subsequent significant economic losses. This disease was originally described by Hemboldt \& Frazier in the USA (1963) in seven-week-old chickens that exhibited necrotizing hepatitis and the presence of inclusion bodies in hepatocytes. In 1987, a new presentation of the disease emerged that was called hydropericardium-hepatitis syndrome (HPS) or Angara disease. HPS was associated with the same group of viruses, and it devastated the poultry industry of Pakistan (Cowen et al. 1978, Hess et al. 1999, Asthana et al. 2013). The syndrome and its various manifestations have been reported in several countries in North and South America, Europe, Asia and Oceania, causing considerable economic losses (Mendelson et al. 1995, Toro et al. 1999, Ono et al. 2003, Rahul et al. 2005, Gomis et al. 2006, Manarolla et al. 2009, Mase et al. 2009, Alemnesh et al. 2010, Choi et al. 2012). Adenoviruses belong to the family Adenoviridae. The genus Mastadenovirus contains adenoviruses that infect mammals, whereas the genus Aviadenovirus has been isolated from birds. Avian adenoviruses are further subdivided into three serological groups (I - III). The Fowl Adenoviruses (FAdVs) belong to Group I, which comprises five species (A to E) and 12 serotypes (1 to 12) and share a common group antigen with viruses isolated from chickens, geese, ducks and turkeys (Alemnesh et al. 2010, Senties-Cue et al. 2010).

In Brazil, the first detection of Fowl adenovirus group 1 (chicken) was demonstrated by antibody detection with immunodiffusion tests for the presence of Avian adenovirus group 1. Although Fowl adenovirus group 1 was present in $78.2 \%$ of serum collected, its expression was not related to any disease (Romero et al. 1989). Recently, another survey demonstrated that turkeys remain free of avian adenovirus group 2 (Moura-Alvarez et al. 2013), and the first molecular detection of FAdV-1 in enteric content related to enteric diseases was performed by our research group (Mettifogo et al. 2014).

This paper describes the first report of Inclusion Body Hepatitis/Hydropericardium Syndrome (IBH/HPS) in Brazilian broiler chickens flocks, identifying avian adenovirus group 1 as a causative agent of the disease. Furthermore, this paper describes the differential diagnosis of IBH/HBS and other viral infections by PCR and observations of clinical signs and pathological lesions.

\section{MATERIALS AND METHODS}

\section{Description of clinical history}

A commercial poultry company's flock of broilers had a continuous history of malabsorption syndrome, with poor weight gain, high feed conversion rates and diarrhea. The onset of these signs began the fourth week of bird life, and signs were more pronounced in flocks that were housed during months with higher temperatures. The farm had 21 flocks, with a population of 22,000 to 41,000 birds per flock and a density of 14.6 to 15.5 birds $/ \mathrm{m}^{2}$. Immunization procedures were routinely performed in the hatchery against Infectious Bronchitis Virus (IBV-Bio Bronk-Vet H120), Infectious Bursal Disease Virus (IBDV-Gumbor-Vet), Marek's disease (HVT-Bio Mark-Vet L) and fowl pox virus (FPV-Bouba Suave). All vaccines were obtained from the Bio Vet Laboratory, Vargem Grande Paulista, SP, Brazil. According to veterinarian reports, some attempts at antibiotic treatments were performed at the onset of signs, including bacitracin at $300 \mathrm{ppm} /$ ton of feed for five days as a preventive treatment. This procedure was repeated 10 days later, no significant improvement was observed.

On 13 March, 2011, two flocks (A and B) were chosen for analysis based on case history, clinical signs, necropsy and laboratory analysis. In the two flocks, the broilers were 41 days old and were at the end of their life cycle. The main clinical signs presented by the broilers were severe diarrhea, prostration, ruffled feathers, depigmentation of the leg skin, severe dermatitis, increased mortality after the fourth week of life, high feed conversion (1: 2.10) and low weight gain. Poultry litter was very wet as a result of severe diarrhea. In flock "A", the mortality rate reached $5 \%$, and the final weight loss was $37 \%$; in flock "B", mortality was $2.4 \%$, and the weight gain was $45 \%$, which was lower than expected.

\section{Virus detection by PCR technique}

Ten chickens (five birds/flock) were sacrificed for postmortem examination. Fragments of the organs with or without gross lesions were collected and frozen at $-20^{\circ} \mathrm{C}$ for PCR to detect the Fowl Adenovirus (FAdVs) Group I hexon gene, and for differential diagnosis for Infectious Bronchitis virus (IBV), avian reovirus, Infectious Bursal Diseases virus (IBDV), and Chicken Anemia virus (CAV) according to the authors in Table 1. All samples were tested in duplicate, since nuclei acid extraction until the final PCR process.

\section{Serology}

Additionally, serum samples (five birds/flock "A" and "B") were also collected to determine the presence of antibodies against Infectious Bronchitis Virus (IBV), Infectious Bursal Disease virus

Table 1. Primers sets, nucleotide sequences, amplicon sizes and the corresponding references that were used to screen for the viruses

\begin{tabular}{|c|c|c|c|c|}
\hline Virus detected & Primers & Nucleotide sequence $\left(5^{\prime}-3^{\prime}\right)$ & $\begin{array}{l}\text { Amplicon size } \\
\text { (bp) }\end{array}$ & Reference \\
\hline $\begin{array}{l}\text { Avian Adenovirus } \\
\text { group I }\end{array}$ & $\begin{array}{l}\text { Hexon A } \\
\text { Hexon B }\end{array}$ & $\begin{array}{c}\text { CAA RTT CAG RCA GAC GT } \\
\text { TAG TGA TGM CGS GAC ATC AT }\end{array}$ & 897 & $\begin{array}{l}\text { Meulemans et al. } \\
2001\end{array}$ \\
\hline $\begin{array}{l}\text { Infectious Bronchitis } \\
\text { Virus }\end{array}$ & $\begin{array}{l}\text { UTR } 41+ \\
\text { UTR } 31 \\
\text { UTR } 11\end{array}$ & $\begin{array}{l}\text { ATG TCT ATC GCC AGG GAA ATG TC } \\
\text { GGG CGT CCA AGT GCT GTA CCC } \\
\text { GCT CTA ACT CTA TAC TAG CCT A }\end{array}$ & 179 & $\begin{array}{l}\text { Cavanagh et al. } \\
2002\end{array}$ \\
\hline Avian Reovirus & $\begin{array}{c}\text { S4-F13 } \\
\text { S4-R1133 }\end{array}$ & $\begin{array}{l}\text { GTG CGT GTT GGA GTT TCC CG } \\
\text { TAC GCC ATC CTA GCT GGA }\end{array}$ & 1120 & $\begin{array}{l}\text { Pantin-Jackwood et al. } \\
2008\end{array}$ \\
\hline $\begin{array}{l}\text { Infectious Bursal } \\
\text { Diseases Virus }\end{array}$ & $\begin{array}{l}\text { VP2F } \\
\text { VP2R }\end{array}$ & $\begin{array}{c}\text { ACC ATA AAC GCC GTG ACC } \\
\text { CCG TGG ATC GTC ACT GCT A }\end{array}$ & 631 & $\begin{array}{l}\text { Yamaguchi et al. } \\
1996\end{array}$ \\
\hline $\begin{array}{l}\text { Chicken Anemia } \\
\text { Virus }\end{array}$ & $\begin{array}{l}\text { CAV4a } \\
\text { CAV4b }\end{array}$ & $\begin{array}{c}\text { GAC TGT AAG ATG GCA AGA CGA GCT C } \\
\text { GGC TGA AGG ATC CCT CAT TC }\end{array}$ & 675 & $\begin{array}{l}\text { Todd et al. } \\
\quad 1992\end{array}$ \\
\hline
\end{tabular}


(IBDV), Reovirus and Chicken Anemia Virus (CAV), but not for Fowl Adenovirus group 1, by competitive enzyme-linked immunosorbent assay (ELISA, Idexx Laboratories, Inc., Westbrook, MN, USA). All sera were screened in duplicate.

\section{RESULTS}

During post-mortem examinations, the classical gross lesions of hepatitis and hydropericardium were mainly observed in flock "A", which presented enlarged, pale yellow-colored livers and straw-colored liquid in the pericardial sac (Fig.1 and 2). Approximately $7 \mathrm{ml}$ of liquid could be extracted from the pericardial sac of a bird from flock "A". Moreover, more birds had organs presenting lesions in flock " $\mathrm{A}$ " than in flock "B". In addition, the intensity of the macroscopic lesions was also more pronounced in flock "A", particularly in the heart, pancreas and duodenum (Table 2). Our results reflect an impairment of the birds from flock "A" and atrophy of the lymphoid organs (thymus and bur$\mathrm{sa}$ ) in the two flocks. ELISA tests performed on both flocks were positive for reovirus and IBV in the flock "A"; CAV and IBDV in the flock "B" (Table 3). According to IBDV and IBV antibodies titer values were consistent with vaccinated birds and did not represent active infection.

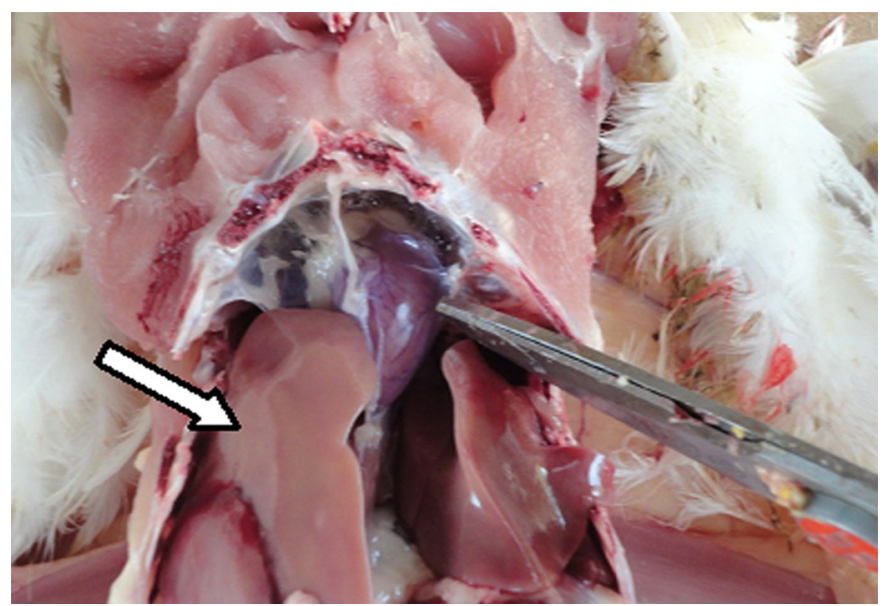

Fig.1. Broiler chicken with hydropericardium and hepatitis. The liver is pale, enlarged and discolored.

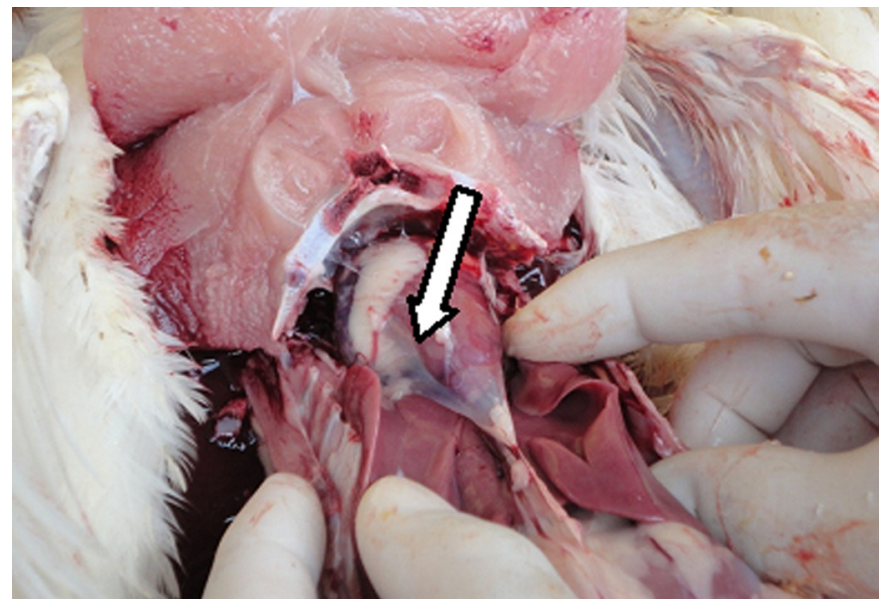

Fig.2. Heart of affected broiler. Characteristic straw-yellow liquid is visible in the pericardial sac.
Table 2. Gross lesions observed in organs during post-mortem examination of five broilers from each flock

\begin{tabular}{lcccc}
\hline \multirow{2}{*}{$\begin{array}{c}\text { Organs } \\
\text { examined }\end{array}$} & Flock A & $+/ \mathrm{n}$ & Flock B & $+/ \mathrm{n}$ \\
\cline { 2 - 5 } Heart & hydropericardium & $(5 / 5)$ & hydropericardium & $(3 / 5)$ \\
Liver & swollen, pale & $(5 / 5)$ & swollen, pale & $(5 / 5)$ \\
Trachea & petechiae & $(1 / 5)$ & petechiae & $(3 / 5)$ \\
Gallbladder & hypertrophied & $(5 / 5)$ & hypertrophied & $(5 / 5)$ \\
Thymus & congested, atrophied & $(5 / 5)$ & congested, atrophied & $(5 / 5)$ \\
Pancreas & atrophied & $(5 / 5)$ & atrophied & $(3 / 5)$ \\
Duodenum & thin wall, suffusions, & $(3 / 5)$ & thin wall, suffusions & $(1 / 5)$ \\
& gases, liquid & & & \\
Cecum & gases, liquid & $(5 / 5)$ & gases, liquid & $(2 / 5)$ \\
Large & undigested food & $(5 / 5)$ & undigested food & $(5 / 5)$ \\
intestine & & & & \\
Spleen & hypertrophied & $(3 / 5)$ & hypertrophied & $(5 / 5)$ \\
Kidneys & hypertrophied & $(5 / 5)$ & hypertrophied & $(5 / 5)$ \\
Bursa & atrophied & $(5 / 5)$ & atrophied & $(5 / 5)$ \\
\end{tabular}

$+/ \mathrm{n}=$ positive samples/number total of samples.

Table 3. ELISA results for Chicken Anemia Virus, Reovirus, Infectious Bronchitis Virus and Infectious Bursal Disease Virus and the average antibody titers of positive samples from the A and B flocks

\begin{tabular}{|c|c|c|c|c|c|c|c|c|}
\hline \multirow[t]{2}{*}{ Agent } & \multicolumn{4}{|c|}{ Flock A } & \multicolumn{4}{|r|}{ Flock B } \\
\hline & $+/ \mathrm{n}$ & PC & $\mathrm{NC}$ & $\begin{array}{c}\text { Positive } \\
\text { samples }^{\ddagger} \text { GMT }\end{array}$ & $+/ \mathrm{n}$ & PC & $\mathrm{NC}$ & $\begin{array}{c}\text { Positive } \\
\text { samples }^{\ddagger \text { GMT }}\end{array}$ \\
\hline CAV & $5 / 10$ & 0.229 & 0.826 & 0.321 & $2 / 10$ & 0,229 & 0.826 & $0.230 \uparrow$ \\
\hline Reovirus & $8 / 10$ & 0.164 & 0.059 & $0.292 \uparrow$ & $6 / 10$ & 0.164 & 0.059 & 0.109 \\
\hline IBV & $5 / 10$ & 0.377 & 0.053 & $0.224 \uparrow$ & $3 / 10$ & 0.377 & 0.053 & 0.150 \\
\hline IBDV & $10 / 10$ & 0.318 & 0.051 & 0.303 & $10 / 10$ & 0.318 & 0.051 & $0.332 \uparrow$ \\
\hline
\end{tabular}

$\overline{\mathrm{CAV}}=$ Chicken Anemia Virus, IBV = Infectious Bronchitis Virus, IBDV = Infectious Bursal Disease Virus, $+/ \mathrm{n}=$ positive samples/total of samples, $\mathrm{PC}=$ positive control, $\mathrm{NC}=$ negative control, ${ }^{\ddagger}$ Average titer of positive samples.

The results of PCR performed on samples of each pool of organs (thymus, liver, pancreas, duodenum, spleen, kidneys and bursa of Fabricius) for the detection of FAdVs group I, CAV, reovirus, IBV and IBDV are shown in Table 4.

The macroscopic lesions of the hydropericardium and pale-swollen liver that were observed in the broilers, together with the PCR results, indicate that the clinical signs observed were predominantly due to an adenovirus infection. In addition to these signs, gross lesions were also present in other organs, and PCR analysis revealed FAdVs group I expression in the thymus, pancreas, kidneys, and duodenum.

\section{DISCUSSION}

Inclusion body hepatitis (IBH) and Hydropericardium syndrome (HPS) have been described as entities characterized by hepatic (swelling, discoloration, ecchymosis or petechial hemorrhages) and renal dysfunction (kidney inflammation, distension of the tubules and degenerative changes). These entities are characterized by basophilic inclusion bodies or eosinophilic hepatocytes and have been associated mainly with the group of adenoviruses belonging to serotypes 4, 8, 11 and 12 (McFerran \& Adair 2003, Alemnesh et al. 2010). Although classical lesions in the heart and liver are characteristic of HPS, FAdVs have also been reported to cause lesions in other organs such as the pancreas, proventriculus, and lymphoid organs and in the respiratory system. Dama- 
Table 4. PCR results for the detection of Fowl Adenovirus (FAdV), Chicken Anemia Virus (CAV), Reovirus, Infectious Bronchitis Virus (IBV), and Infectious Bursal Disease Virus (IBDV) from samples of several organs of chickens from flocks $A$ and $B$

\begin{tabular}{|c|c|c|c|c|c|c|c|c|c|c|c|c|c|c|}
\hline \multirow[t]{2}{*}{ Agent } & \multicolumn{7}{|c|}{ Flock A } & \multicolumn{7}{|c|}{ Flock B } \\
\hline & Thymus & Liver & Pancreas & Duodenum & Spleen & Kidneys & Bursa & Thymus & Liver & Pancreas & Duodenum & Spleen & Kidneys & Bursa \\
\hline FAdV & + & + & - & - & + & + & + & - & + & - & - & + & - & + \\
\hline CAV & - & - & - & - & - & - & - & - & - & - & - & - & - & - \\
\hline Reovirus & - & - & - & - & - & - & - & - & - & - & - & - & - & - \\
\hline IBV & - & - & - & - & - & - & - & - & - & - & - & - & - & - \\
\hline IBDV & - & - & - & - & - & - & - & - & - & - & - & - & - & - \\
\hline
\end{tabular}

ge to these organs caused by adenoviruses has been described previously, both alone and in combination with other viruses (Cowen et al. 1978).

In this report, atrophy of lymphoid organs (thymus and bursa) was observed in both flocks (A and B) and was associated with both FAdVs group I and CAV. Similar pathological lesions in lymphoid organs have been described in broilers with CAV. These lesions include thymic, splenic and bursal atrophy, aplastic bone marrow and anemia, which may vary in severity depending on the presence of other pathogens (Adair 2000). However, the increased intensity of gross lesions in flock "A", which had lower antibody titers and was negative for CAV as assessed by PCR, suggests that the detected serotype of FAdV is capable of inducing the macroscopic lesions observed in these lymphoid organs.

Based on the available information on the vaccination programs performed at the hatchery against IBV and IBVD and the results obtained here, the lower antibody titers against the diseases observed in flocks A and B indicated that these antibodies were induced by vaccination and not by field virus infection. By contrast, the antibody titers against reovirus indicate a field virus infection because the flocks were not vaccinated against this disease. However, PCR analysis revealed that the organs were negative for reovirus. Although reovirus has been reported to cause injuries similar to those caused by FAdV (Ni \& Kemp 1995), this virus causes tenosynovitis and consequently was not considered to be one of the possible causative agents of the signs observed in the chickens in this report.

CAV antibodies were higher in flock B, in which the signs and gross lesions were less intense than those observed in flock A. Furthermore, the PCR results indicated that this flock was negative for CAV. It has long been believed that adenoviral IBH results only when birds are also infected with IBDV, CAV, or other immunocompromising agents (McFerran \& Adair 2003). In the 1970s, researchers were able to reproduce the disease using isolates from infected birds presenting lesions in the lymphoid tissue (McCracken et al. 1976, Grimes et al. 1977). Outbreaks of IBH in which no immunosuppressive pathogens were detected have been reported in Northern Ireland, Australia, Korea and New Zealand - countries that have experienced epidemic outbreaks of IBH in the absence of IBDV (Reece et al. 1986, Christensen \& Saifuddin 1989, Choi et al. 2012). Experiments performed by Toro and colleagues could not confirm the hypothesis that the association of CAV and FAdVs group I is necessary for the induction of IBH/HP syndrome (Toro et al. 2001). Those authors followed the premise that certain isolates, such as FAdV-4, can reproduce the syndrome by themselves, but other strains appear to require the presence of an immunosuppressive agent.

According to our results, the hepatitis and hydropericardium observed in the broilers were caused mainly by FAdV Group I. The presence of CAV according to ELISA and its accompanying immunosuppressive effects most likely caused a synergistic effect with FAdV that may have accentuated the general signs. To our knowledge, this is the first report of FAdV infection causing hepatitis and hydropericardium syndrome in Brazil. Further investigation is needed to verify the spread of this virus in Brazilian poultry flocks.

\section{CONCLUSION}

This is the first report of Inclusion body hepatitis/hydropericardium syndrome (IBH/HPS) caused by Fowl Adenovirus group I in Brazil. Indeed, this description may contribute to the worldwide epidemiology of adenovirus-mediated hepatitis/hydropericardium syndrome.

Acknowledgments.- This study was sponsored by FAPESP (Fundação de Amparo à Pesquisa do Estado de São Paulo), grant \#06/59332-9, and CNPq (Conselho Nacional de Desenvolvimento Científico e Tecnológico).

\section{REFERENCES}

Adair C.W. 2000. Immunopathogenesis of chicken anemia virus infection. Dev. Comp. Immunol. 24:247-255.

Alemnesh W., Hair-Bejo M., Aini I. \& Omar A.R. 2010. Pathogenicity of fowl adenovirus in specific pathogen free chicken embryos. J. Comp. Pathol. 1:1-7.

Asthana M., Chandra R. \& Kumar R. 2013. Hydropericardium syndrome: current state and future developments. Arch. Virol. 158:921-931.

Cavanagh D., Mawditt D., Welchman B., Britton P. \& Gough R.E. 2002. Coronaviruses from Pheasants (Phasianuscolchicus) are genetically closely related to coronaviruses of domestic fowl (infectious bronchitis vírus) and turkeys. Avian Pathol. 31:81-93.

Choi K.S., Kye S.J., Kim J.Y., Jeon W.J., Lee E.K., Park K.Y. \& Sung H.W. 2012. Epidemiological investigation of outbreaks of fowl adenovirus infection in commercial chickens in Korea. Poult. Sci. 91:2502-2506.

Christensen N.H. \& Saifuddin M.D. 1989. A primary epidemic of inclusion body hepatitis in broilers. Avian Dis. 33:622-630.

Cowen B., Mitchell G.B. \& Calnek B.W. 1978. An adenovirus survey of poultry flocks during the growing and laying periods. Avian Dis. 22:115-121.

Gomis S., Goodhope A.R., Ojkic A.D. \& Willson P. 2006. Inclusion body hepatitis as a primary disease in broilers in Saskatchewan, Canada. Avian Dis. 50:550-555.

Grimes T.M., King D.J., Kleven S.H. \& Fletcher O.J. 1977. Involvement of a type- 8 avian adenovirus in the etiology of inclusion body hepatitis. Avian Dis. 21:26-38. 
Helmbolt C.F. \& Frazier M.N. 1963. Avian hepatic inclusion bodies of unknown significance. Avian Dis. 7:446-450.

Hess M., Raue R. \& Prusas C. 1999. Epidemiological studies on fowl adenoviruses isolated from cases of infectious hydropericardium. Avian Dis. 28:433-439.

Manarolla G., Pisoni G., Moroni P., Gallazzi D., Sironi G. \& Rampin T. 2009. Adenoviral gizzard erosions in Italian chicken flocks. Vet. Rec. 164:754756.

Mase M., Mitake H., Inoue T. \& Imada T. 2009. Identification of group I-III avian adenovirus by PCR coupled with direct sequencing of the hexon gene. J. Vet. Med. Sci. 71:1239-1242.

McCracken R.M., McFerran J.B., Evans R.T., Connor T.J. 1976. Experimental studies on the a etiology of inclusion body hepatitis. Avian Pathol. 5:325-339.

McFerran J.B. \& Adair B.M. 2003. Group I Adenovirus Infections, p.214-227. In: Saif Y.M., Fadly A.M., Glisson J.R., McDougald L.R., Nolan L.K. \& Swayne D.E. (Eds), Diseases of Poultry. $12^{\text {th }}$ ed. Blackwell Publishing, Iowa.

Mettifogo E., Nuñez L.F., Chacón J.L., Santander Parra S.H., Astolfi-Ferreira C.S., Jerez J.A., Jones R.C. \& Piantino Ferreira A.J. 2014. Emergence of enteric viruses in production chickens is a concern for avian health. Scientific World Journal. ID 450423. http://dx.doi: 10.1155/2014/450423.

Meulemans G., Boschmans M., Van den Berg T.P. \& Decaesstecker M. 2001. Polymerase chain reaction combined with restriction enzyme analysis for detection and differentiation of fowl adenoviruses. Avian Pathol. 30:655-660.

Mendelson C., Nothelfer H.B. \& Monreal G. 1995. Identification and characterization of an avian adenovirus isolated from a "spiking mortality syndrome" field outbreak in broilers on the Delmarva. Pennsilvania, USA. Avian Pathol. 24:693-706.

Moura-Alvarez J., Chacon J.V., Scanavini L.S., Nuñez L.F., Astolfi-Ferreira C.S., Jones R.C. \& Piantino Ferreira A.J. 2013. Enteric viruses in Brazilian turkey flocks: single and multiple virus infection frequency according to age and clinical signs of intestinal disease. Poult. Sci. 92:945-955.

Ni Y. \& Kemp M.C. 1995. A comparative study of avian reovirus pathogenicity: virus spread and replication and induction of lesions. Avian Dis. 39:554-566.
Ono M., Okuda Y., Yazawa S., Shibata I., Sato S. \& Okada K. 2003. Outbreaks of adenoviral gizzard erosion in slaughtered broiler chickens in Japan. Vet. Rec. 153:775-779.

Pantin-Jackwood M.J., Day J.D., Jackwood M.W. \& Spackman E. 2008. Enteric viruses detected by molecular methods in commercial chicken and turkey flocks in the United States between 2005 and 2006. Avian Dis. $52: 235-244$

Rahul S., Kataria J.M., Senthilkumar N., Dhama K., Sylvester S.A. \& Uma R. 2005. Association of fowl adenovirus serotype 12 with hydropericardium syndrome of poultry in India. Acta Virol. 49:139-143.

Reece R.L., Grix D.C. \& Barr D.A. 1986. An unusual case of inclusion body hepatitis in a cockerel. Avian Dis. 30:224-227.

Romero C.H., Brentano L., Rowe C.A., Wentz I., Flores R.S. \& Rodrigues J.C. 1989. Ocorrência de anticorpos para vírus aviários em frangos de corte em região de intensa produção avícola. Pesq. Vet. Bras. 9:1-7.

Senties-Cue C.G., Wills R.W., Stayer P.A., Burleson M.A. \& Magee D.L. 2010. Epidemiology and Effect of Production Parameters of an Outbreak of Inclusion Body Hepatitis in Broilers. Avian Dis. 54:74-78.

Todd D., Mawhinney K.A. \& McNulty M.S. 1992. Detection and differentiation of chicken anemia virus isolates by using the polymerase chain reaction. J. Clin. Microbiol. 30:1661-1666.

Toro H., González O., Escobar C., Cerda L., Morales M.A. \& Gonzalez C. 2001. Vertical induction of the inclusion body hepatitis/hydropericardium syndrome with fowl adenovirus and chicken anemia virus. Avian Dis. 45:215-222.

Toro H., Prusas C., Raue R., Cerda L., Geisse C., González C. \& Hess M. 1999. Characterization of fowl adenoviruses from outbreaks of inclusion body hepatitis/hydropericardium syndrome in Chile. Avian Dis. 43:262-270.

Wang J., Zhu L., Zhu J., Sun H. \& Zhu G. 2011. Molecular characterization and phylogenetic analyses of an avian adeno-associated virus originating from a chicken in China. Arch. Virol. 77:71-77.

Yamaguchi T., Ogawa M., Inoshima Y., Miyoshi M., Fukushi H. \& Hirai K. 1996. Identification of sequence changes responsible for the attenuation of highly virulent infectious bursal disease virus. Virology 223:219223. 